\title{
The Role of an Ideal ESP Practitioner
}

\author{
Hussein Hassan Ibrahim \\ Department of English Language, Faculty of Arts, University of Sinnar, Sinnar, Sudan \\ Email: karkad1967@hotmail.com
}

How to cite this paper: Ibrahim, H. H. (2019). The Role of an Ideal ESP Practitioner. Open Journal of Modern Linguistics, 9, 76-91.

https://doi.org/10.4236/ojml.2019.92008

Received: February 12, 2019

Accepted: April 9, 2019

Published: April 12, 2019

Copyright $\odot 2019$ by author(s) and Scientific Research Publishing Inc. This work is licensed under the Creative Commons Attribution International License (CC BY 4.0).

http://creativecommons.org/licenses/by/4.0/

\section{(c) (i) Open Access}

\begin{abstract}
This paper aims to reflect onthe role of an ideal ESP practitioner. There are a lot of challenges and problems which affect an ESP practitioner to teach ESP courses such as lack of modern use of technology and lack of learners' motivation. The paper starts with key concepts about ESP. Then; it discusses the role of an ESP practitioner. Next, problems and challenges affect teaching ESP. Finally, the status of an ESP today is presented. The researcher followed a descriptive method to shed some lights on the variety of the topics to make clear distinction especially between a general English (GE) teacher and the English for Specific Purposes (ESP) teacher and to what extent they are different. The findings of this paper showed that lack of training and lack of specialist knowledge were considered as the main obstacles. It is recommended for any educational institutions to train ESP practitioners in advance before starting to teach ESP courses/programs. It also recommended for educational institutions to establish ESP Units in order to overcome the challenges and problem.
\end{abstract}

\section{Keywords}

Practitioner, ESP, Learners, Role, General English (GE), Teacher, Need, Ideal

\section{Introduction}

The comprehensive need for English for Specific Purposes (ESP in short) practitioners led the educational authorities to adopt an approach that serves certain areas of study such as medicine, science, trade, law, tourism, employment, computer, engineering, vocational and migration of study in the field of education. Therefore, a great deal of countries have encouraged learning English to achieve specific purposes in certain fields. Accordingly, the ESP practitioners and their learners need language courses to perform their specific needs. For that reason, there is a focus in learner-centred approach, which has great effects in the emergence of certain language programs to be taught so as to achieve the 
specific learners' needs. Thus, the new trends in this field of language teaching led the educational system to train teachers as to be qualified to teach the courses upon the learners' central needs. The new trend towards learning English also has changed the concept of grammar translation method for a set of rules to language communication method as explained by Widdowson (1978) and Hutchinson and Waters (1987). Dudley-Evans and St. John (1998) have assumed that ESP is a multi-dimension approach which required a variety of roles to perform. These roles are assigned to the ESP practitioner such as researcher, course designer and material developer, language instructor, learning assessor, course evaluator, collaborator, facilitator, creative, and motivator. To perform these roles, the ESP practitioner should have a significant awareness of psychological needs, profound knowledge, and open minded, curious and enthusiastic with ESP. That is why John Swales (1985) prefers to use the concept of an ESP practitioner instead of an ESP teacher for the variety of roles and not to just a teacher. As a result, an ESP practitioner should be up-to-date (i.e. aware of latest developments in the field of language teaching). Therefore, the area in which we teach, decides which specific terms should be used and how to build learners' motivation. For example, if we want to teach business students, the teacher should adopt creative and convenient techniques to encourage students to learn the language (Hussin et al., 2000). As such, if the students are much motivated to learn the language, they will find themselves much interested in dealing with their subject-matter. For that reason, learning a language should not be only for academic practice but also for job-related purposes and for social communication.

\section{Key Concepts about ESP}

ESP is considered as a language teaching approach. As such, there are six main notions, which figure out the concepts about ESP 1) the origin of ESP, 2) ESP teacher vs. GE teacher, 3) the definition of ESP, 4) types of ESP courses, 5) characteristics of ESP courses, 6) the concept of the word "special" in ESP.

\subsection{The Origin of ESP}

There are three key reasons resulted in the emergence of ESP as identified by (Hutchinson \& Waters, 1987). These reasons are as follows:

1) The Demands of a Brave New World;

2) The Revolution in Linguistics;

3) Focus on the Learner.

\subsubsection{The Demands of a Brave New World}

This reason has been influenced by two key factors. These two factors are: The End of the Second World War and The Oil Crisis.

The first factor has great effect on the expansion in science, technology and economy. Hutchinson \& Waters, 1987 clarified this point in the following statement: 
“... age of enormous and unprecedented expansion in scientific, technical and economic activity on an international scale for various reasons, most notably the economic power of the United States in the post-war world, the role [of international language fell to English]" (p. 6).

The second factor has to do with the English language teaching as a means of communication between nations to pass on the needed goods (Hutchinson \& Waters, 1987: p. 7).

\subsubsection{The Revolution in Linguistics}

The revolution in linguistics focused on the ways of how to use language in real life situations. Regarding this issue, it is found that the language used in spoken and written situations is subject to change. Historically, in the late 1960s and the early 1970s, some great efforts were made to describe English for Science and Technology (Hutchinson \& Waters, 1987).

\subsubsection{Focus on the Learner}

The last reason focuses on the methodology to teach language according to the learners' needs and interests. As such, Hutchinson and Waters (1987) look at the learner as the central focus of learning and teaching processes as they have different learning strategies, different needs, interests and different skills to acquire the language, and they should be motivated. This trend led to designing ESP courses that meet their needs and the focus was on learner-centred or learning-centred approach.

\subsection{ESP Teacher vs. GE Teacher}

In the early 1960s, the nature of English language teaching experienced some changes. These changes led some researchers to create a number of comparisons between ESP teachers and GE teachers. Strevens (1988) indicates that the ESP teachers are simply GE teachers who were trained with ESP courses to teach specific groups of learners. Likewise, Anthony (1997) used to describe ESP teacher as GE teachers based on needs analysis and the use of English in certain situations. However, Anthony's ideas have been faced by some criticisms as some researchers believe that ESP teachers are not as the same as their counterpart (GE teachers). The criticisms of the researchers are as follows:

1) GE teachers are the master of the class and should be obeyed, but in ESP there is much freedom as learners are adults (Larson-Freeman, 2000).

2) GE teachers are only keen for lesson preparation and evaluation (William, 2010).

3) GE teachers spend a smaller amount of effort than what their counterpart do. To make it clear, the ESP teachers spend great effort to do other functions such as needs analysis; material provider and syllabus designer. Whereas GE teachers equip their learners with grammar rules, phonemes, morphemes, history of language and just to be learnt by heart in most cases. ESP teachers focus on communicative needs. 


\subsection{The Definitions of ESP}

ESP has followed several definitions due to its rapid development in many areas. Accordingly, a lot of researchers and elites such as Hutchinson and Waters (1987), Robinson (1991), Strevens (1988), and Dudley-Evans and St. John (1998) have contributed a lot to this field of knowledge. They prefer to define ESP as an approach rather than a product, which refers to that an ESP, is not following a specific type of language, teaching materials or methodology. This type of issue depends on the primacy of requirement in ESP, which represents the leading trend in the majority of ESP definitions.

Hutchinson and Waters (1987), in particular, decide that "the foundation of ESP is the simple question: Why does this learner need to learn a foreign language?". The responding to this simple question requires concern of the learner, the language, and the context through which learning takes place; and these all converge the trends of the basic need in the field of ESP. The concept of need identified by the reasons urges the learner to learn English. However, these reasons differ according to the purposes, which focus on the language that one pursues.

Through years, the perception of this movement/trend has brought a global knowledge and understanding criteria in the mind of an ESP teacher (practitioner). ESP as seen by the eyes of the famous researchers and pioneers, is considered to engage a combination of both criteria of "needs analysis" and "characteristic features", for example, Robinson's (1991) criterial features embrace goal-directedness and needs analysis. Mackay (1978) stated that "an increasing number of scholars, practitioners and institutions to mean English for Specific Purposes" use ESP.

Others, such as Strevens (1988), Dudley-Evans and St. John (1998) have a preference to look at the definition of ESP through absolute and variable characteristics. Since tracing these important views about the definitions of ESP, a universal appropriate definition cannot be made to suit any practitioner due to the different notions of this field that are delivered by many people who support this area of research. From the above view, it would be clear that the definitions introduced by Hutchinson and Waters (1987), Strevens (1988), Robinson (1991), Fanning (1993), and Dudley-Evans and St. John (1998), can be considered as a conclusive definition to ESP, which concerns the "traits" on ESP. These traits are classified into two types, basic and common. An ESP course always has some traits whether they are basic or they can be common to exist. The following traits found in ESP courses, which are divided into two traits:

\section{Basic Traits are as follows:}

- Approach rather than a product (as mentioned before), meaning that there is no definite task/skills, materials or methodology;

- Driven by the needs and/or purposes of the learners themselves, or others who are less directly involved (primary and secondary consumers of the learners' task); 
- Specific, but specificity is on a continuum of Quite to Very (refer to Robinson's definition in 1988);

- Need to focus on the philosophy and thinking of the discipline(s) of the learner as well as on the activities of the discipline. The needs/purposes of the learners does not relate to a discipline or their current learning;

- They focused on language varieties such as (grammar, lexis, and register), skills, discourse and genres appropriate to these activities.

\section{Common Traits.}

- Usually designed for adult learners;

- Learners normally have a basic or intermediate knowledge of the English Language;

- Normally constrained by a limited time;

- Levels of homogeneity can vary- "Quite" to "Very".

ESP considered as a notable work that has been invaded the world in the recent years due to its wide concerns to include many specific areas such as commerce, science and technology, business, etc. As its trend to be emerged as a work, it followed what called "approach" and not "product". This trend identifies the way it precedes "how" and not just obtaining the result (product). Because of this trend, ESP has witnessed great development and definitions accordingly. Many definitions have given to the ESP approach to shape its significance as a valuable work, which forced the nations to pay more attention to it. In this respect, Robinson (1980) defined it as "Quintessential ESP, if we can pinpoint it, is perhaps this: materials produced for use once only by one group of students in one place at any one time". He also adds "English for specific purposes for specific people". Hutchinson and Waters (1987) defined it as follows:

- Approach rather than a product, which meaning, ESP does not involve a particular type of materials or methodology for teaching a language. They suggest that "the foundation of ESP is the simple question: Why does this learner need to learn a foreign language?". This question relates to the learners, the language required, and the learning context. This leads to the primacy of need in ESP.

- The primacy of need in ESP. Need is defined by the reasons for which the student is learning English. It can be something quite general like wanting to follow a postgraduate course in an English speaking country to participating in business meetings or taking hotel bookings.

The theorist Swales (1986) went to some extent by saying that "English for specifiable Purposes". The new addition he made, he wanted to show specific notions about "specific" and "specifiable" as follows:

- Specific: already identified in terms of purposes.

- Specifiable: focuses on the pre-planning process necessary for ESP coursesinvestigation, exploration, and identification and attempts to specify as much of the present and future environment of the learners as it is practical in the limited time available.

- The Question is; who is responsible for the task of specifying? Teacher? 


\section{Learners?}

Following the above statements, one can easily discover what the differences resulted in their claims and assumptions they made. Dudley-Evans and St. John have detached the absolute characteristic that "ESP is in contrast with General English" and added more characteristics that are variable. So, ESP, as an educational science, doesn't mainly relate to certain area. Moreover, ESP used with adult learners and it could be used with young adults in a secondary school setting.

Concerning this article, there appeared a broader definition of ESP, Hutchinson and Waters (1987) theorize, "ESP is an approach to language teaching in which all decisions as to content and method are based on the learner's reason for learning" (p. 19). Anthony (1997) notes that, it is not clear where ESP courses end and general English courses begin; numerous non-specialist ESL instructors use an ESP approach in that their syllabi are based on analysis of learner needs and their own personal specialist knowledge of using English for real communication. In the above statement, it is clear that the main reason for the emergence of an ESP course is as a means of communication, regarding a lot of areas. As such, Dudley-Evans and St. John (1998) tailored Strevens' original definition of ESP to have their own definition. Strevens (1988) categorised ESP from two perceptions: changing and fixed classifications:

\section{1) Absolute Characteristics}

ESP consists of English language teaching which is:

- Designed to meet specified needs of the learner;

- Belonged to special area of study such as job, training sessions, and other contents;

- Focused on linguistic s areas such as morphology, syntax, lexicology, ..., and their analytical concepts;

- In contrast with General English.

\section{2) Variable Characteristics}

ESP may be, but is not necessarily:

- Focused on some of the four skills (not all);

- Followed a variety of methods in teaching.

Anthony (1997) states that there has been considerable argument about the meaning of ESP in spite of the fact that it is considered as an approach which has been widely used over the world within the last three decades. At a 1997 Japan Conference on ESP, Dudley-Evans and St. John offered a modified definition that concerning absolute and variable characteristics as follows:

\section{1) Absolute Characteristics}

- focused on special learner's desire;

- followed principal method and certain usage;

- focused on the four skills of the language and building skills.

\section{2) Variable Characteristics}

- Possibly intended for special areas;

- Possibly used different techniques of teaching in specific programs in con- 
trast with general English;

- Planned for mature people in different areas of study;

- Planned for mature students from intermediate level to higher levels;

- The majority of ESP learners had prior awareness of the program.

There is a definition of ESP, which belongs to Robinson (1991). She states the following statement in her definition:

- Primacy of needs analysis;

- Key criteria:

a) Normally goal-directed;

b) Normally defines what the learner's needs are;

- Characteristics:

1) ESP courses generally constrained by a limited time period;

2) Taught to adults;

3) ESP courses are for learners of the same class (i.e. job or area of expertise).

\subsection{Types of ESP Courses}

ESP is viewed by a number of researchers as an umbrella of teaching and learning English in a number of fields for specific purposes: EAP (English for Academic Purposes), EOP (English for Occupational Purposes). EAP is applied in educational institutions where students learn it for their academic purposes (Kennedy \& Bolitho, 1984). In an EAP course, students are expected to acquire receptive and perceptive academic skills parallel to developing learning strategies and study skills (Jordan, 1997). Meaning that EAP programmes have been built up for the purpose of teaching particular skills to learners in order to enhance them pursue their academic career and obtain basic skills, which to some extent enable them to do well in workplace. Dudley-Evans and St. John (1998) state that the development of EAP curriculum is led by the needs of the learners, saying that: "identifiable elements of the target situations". Likewise, Robinson (1991) agrees with them by mentioning that the EAP requires academic needs for study. Whereas EOP is mainly designed for the purpose of workplace needs and training (Robinson, 1991; Hutchinson \& Waters, 1987), for example, English for doctors, air-traffic controller, and technicians, etc. One can notice that there is clear or rationale distinction between EAP \& EOP (Hutchinson \& Waters, 1987) and they both overlap because one can practice both of them at the same place (work and study) now or later on. Within the given diversity and complexity of EAP objectives, it is essential to follow an in-depth needs assessment before planning and implementing an EAP curriculum and material (Johns, 1991; Robinson, 1991).

David Carter (1983) mentions three types of ESP Courses:

- English as a restricted language;

- English for academic and occupational purposes;

- English with specific topics.

The language used by hotel waiters, air-traffic controller, and telecommunication are examples of English as a restricted language, that is, specific language. 
Mackay (1978) obviously explain the difference between restricted language and common language with this statement:

... The language of international air-traffic controller is regarded as "special", in the sense that the repertoire required by the controller is strictly limited and can be accurately determined situationally, as might be the linguistic needs of a dining-room waiter or airhostess. However, such restricted repertoires are not languages, just as a tourist phrase book is not grammar. Knowing a restricted "language" would not allow the speaker to communicate effectively in novel situation, or in contexts outside the vocational environment (pp. 4-5).

The second type of ESP, which explained by Carter (1983) is English for Academic and Occupational Purposes. In the "Tree of ELT" (Hutchinson \& Waters, 1987), ESP is broken down into three branches: 1) English for Science and Technology (EST), 2) English for Business and Economics (EBE), and 3) English for Social Studies (ESS). Each one of these subject areas is divided into two branches: English for Academic Purposes (EAP) and English for Occupational Purposes (EOP). An example of EOP for the EST branch is "English for Technicians" whereas an example of EAP for the EST branch is "English for Medical Studies".

Hutchinson and Waters (1987) strongly argue that there is not a clear-cut distinction between EAP and EOP as presented in the following statement:

"people can work and study simultaneously; it is also likely that in many cases the language learnt for immediate use in a study environment will be used later when the student takes up, or returns to, a job" (p. 16).

Nevertheless, it is clear that the above statement describes Carter's rationale for classifying EAP and EOP under the same type of ESP. It is that, Carter is implying the end purpose of both EAP and EOP are in the same employment. However, despite the end purpose being identical, the means taken to achieve the end is very different indeed. In my opinion, the classification of EAP and EOP are different in terms of focus on Cummins' (1979) notions of cognitive academic proficiency versus basic interpersonal skills.

The last type of ESP illustrated by Carter (1983) is English with specific topics. He explains that the focus changes from "purpose" to "topic". This type of ESP is uniquely concerned with anticipated future English needs such as attending conferences, doing researches in specific fields or working in foreign institutions. However, I argue that this is not a separate type of ESP. Relatively; regarded as an integral component of ESP courses or programs that focus on situational language. This situational language has been determined based on the interpretation of results from needs analysis of authentic language used in target workplace settings. This identifies the need for an ESP course within the purpose of serving needs analysis to accomplish certain goals relevant to it.

Figure 1 shows the classification of ESP. Traditionally, ESP, divided into two main areas: English for Academic Purposes (EAP) and English for Occupational 


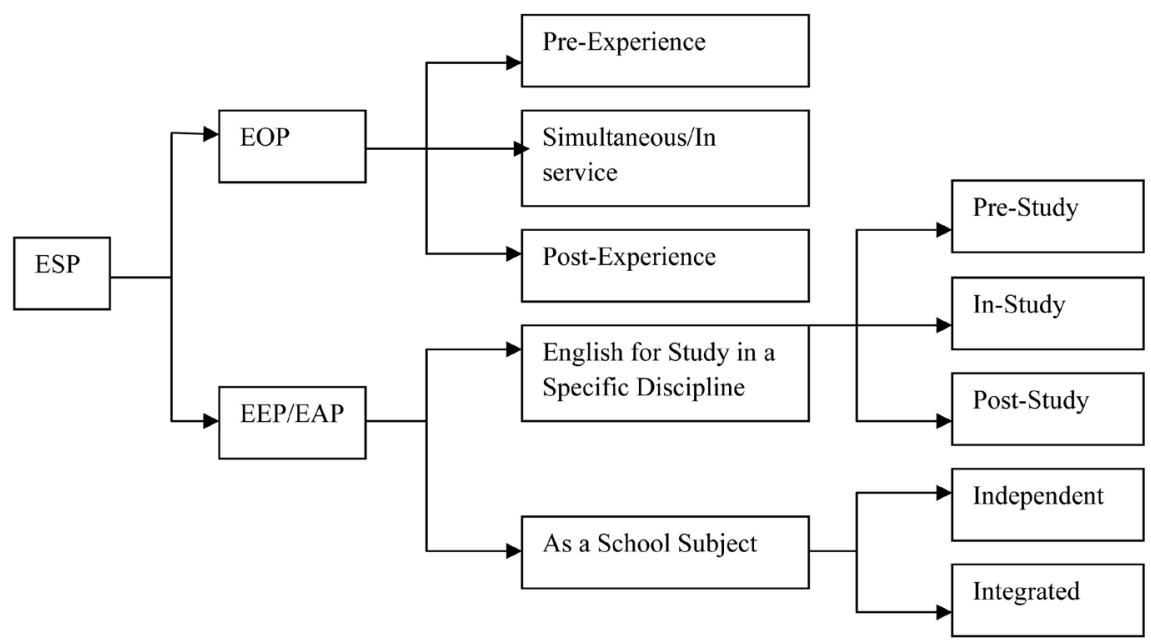

Figure 1. The classification of ESP by experience.

Purposes (EOP). The figure shows the traditional classification of ESP according to Robinson (1991: pp. 3-4).

Figure 2, shows ESP classification by professional area as explained by Hutchinson and Waters (1987). From Figure 2, ESP is classified into three subdivisions, that is, vocational, professional, and academic. The vocational area consists of two subdivisions, that is, English for Academic Purposes and English for Specific Purposes (specific discipline). The professional area composes of three subdivisions, English for Social Purposes, English for business purposes, and English for technology. The last area of ESP is English for Academic Purposes, which consists of entry Vocational English as a Second Language and literacy.

Figure 3, as in EAP, EST represents the essential part of which EMP \& ELP have categorized. On the other hand, EOP includes English for Professional Purposes in administration, medicine, law and business, and vocational purposes for non-professional in work or pre-work situations. One may notice a little confusion between EMP as part of EAP and EMP as part of EOP. The former refers to medical students while the latter refers to doctor training or practice. EOP can be branched into two categories: Vocational English, which studies the language in terms of training for "specific trades or occupations", and pre-vocational English, which concentrates on "finding a job and interview".

According to the examples introduced above, it is important to consider specificity when designing an ESP course, that is, specificity and motivation shape one face for a course to be effective for learners. So specifying needs play an important role towards course design. Following this issue, Strevens (1988) concluded stating that the benefit of ESP course is in the following trends:

- Being focused on the learner' need, it wastes no time;

- It is relevant to the learners;

- It is successful in imparting learning;

- It is more cost-effective than "General English".

Through tracing the classification of ESP, I find the statement introduced by 


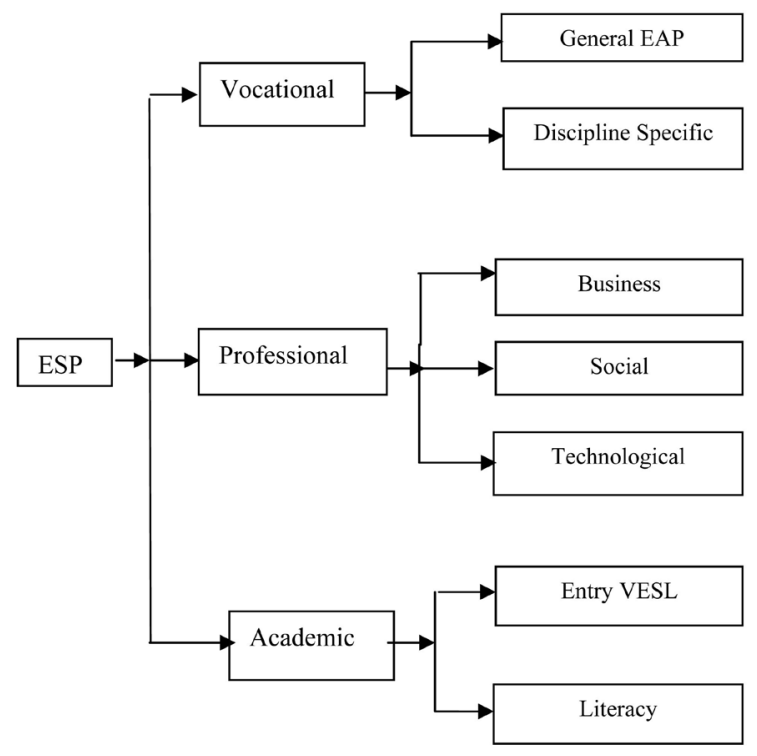

Figure 2. ESP classification by professional area (Hutchinson \& Waters, 1987).

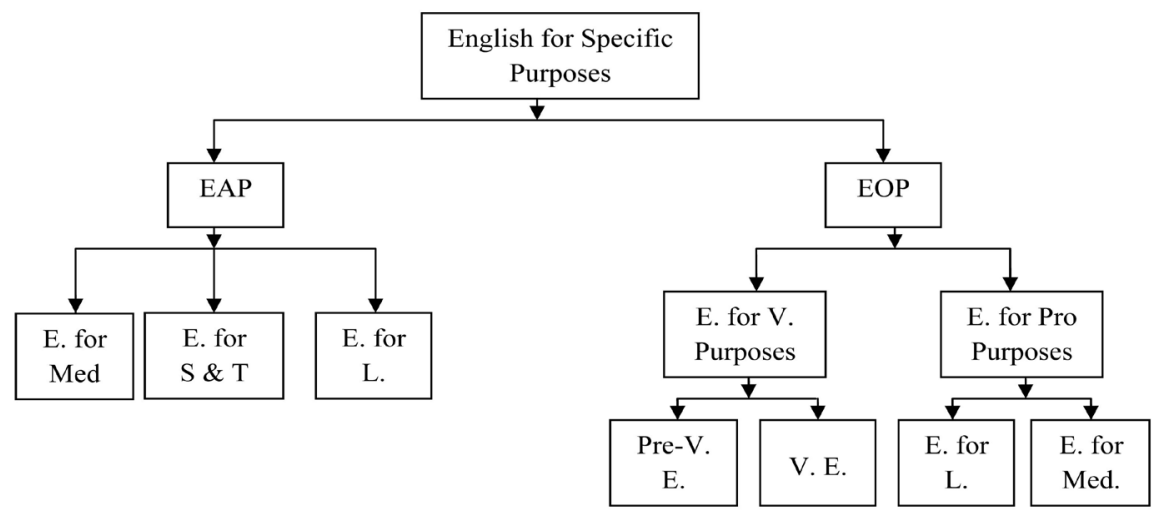

Figure 3. Conception of the EAP and EOP (Hutchinson \& Waters, 1987). Key: E = English $; \mathrm{V}=$ Vocational; Med. = Medical; $\mathrm{S}=$ Science; $\mathrm{T}=$ Technology; $\mathrm{L}=$ Legal; Pro= Professional.

Robinson serves as rationale account for ESP in general and EAP in special as coming below:

"EAP accounts for a large amount of ESP activity ... EAP is a branch of ESP, EAP can appear to be very general in scope, however, as the same courses and materials can be aimed at students from a variety of academic disciplines. Within such general courses we might find components aimed at students from specific discipline".

It is notable to notice that, here the students have not exposed to an in-depth ESP programme. Thus, they are unable to deal with the demands of their own disciplines.

\subsection{The Characteristics of ESP Courses}

The characteristics of ESP courses stated by Carter (1983) are in the following 
piece of writing. He illustrates that there are three features common to ESP courses: Authentic material, Purpose-related orientation and Self-direction.

\subsubsection{Authentic Material}

In the course of reviewing the statement produced by Dudley-Evans' (1997) claim, it is obvious that ESP should be offered at an intermediate or advanced level, and the use of authentic learning materials is completely practicable. $\mathrm{He}$ goes further by suggesting closer examination of ESP materials, which claimed as to meet the learners' requirements. He also argues this stage of use of authentic content materials, modified or unmodified in form, are indeed a feature of ESP, particularly in self-directed study and research tasks. Accordingly, he noticed that this opinion agrees to Carter's views on method towards adult learning as he introduced advance, because self-directed learning used much with adult learners. Comparatively, when the need for language preparation for employment in health science, for example, displays a large component of the student evaluation, which based on an independent study assignment in which the learners were required to investigate and present an area of interest. The students were encouraged to conduct research through using a variety of different resources, including even the Internet for collecting their data.

\subsubsection{Purpose-Related Orientation}

The second characteristic of ESP is the Purpose-related orientation, which refers to the impact of communicative tasks required for the target setting, language for communicative purposes. In this point, Carter (1983) states the attendants' simulation of a conference, involving the preparation of papers, reading, note taking, and writing.

\subsubsection{Self-Direction}

The third and final characteristic of ESP is self-direction courses in that the "... point of including self-direction... is that ESP is concerned with turning learners into users" (Carter, 1983: p. 134). Learners' degree of freedom is the basic towards self-direction to take place or decide when, what, and how they will study. Carter (1983) also suggests that a systematic attempt (learning strategies), which is followed by teachers to teach the learners how to learn (learners' autonomy). Though it is necessary, to teach high-ability learners how to activate and access the required information in a new culture. Accordingly, learners' autonomy is an important method of teaching in recent years towards ELT and this approach resulted in motivating learners by both directing and giving them freedom.

\subsection{The Concept of the Word "Special” in ESP}

There are two notions concerning the word "special". To make clear of these two notions, the following clarification is special language and specialized aims are two completely different notions. Perren (1974) was the one who made a note of that confusion arises over these two notions. Mackay and Mountford's restricted repertoire, make use of the idea of a special language. Dudley Evans and St. John 
(1998) state: the only practical way in which we can understand the notion of special language is as a restricted repertoire of words and expressions selected from the whole language because that restricted repertoire covers every requirement within a well-defined context, task or vocation (p. 4).

The concept of a "specialized aim" refers to the purpose towards learning a language, but not the nature of the language they learn (Mackay, 1978). Consequently, the concept of the word "special" in ESP is due to the purpose for learning as mentioned above and not the specific language or the record about the language they learn.

\section{The Role of an ESP Practitioner}

There are some roles that every an ideal (perfect) ESP practitioner should obtain to perform teaching processes. The ideal ESP practitioner is the person who underwent some training before entering the field of teaching. The majority of researchers in the field of ESP state that an ESP practitioner's job involves much more than just teaching. In other words, there are some other roles to do besides teaching itself. Therefore, some researchers like Dudley Evans and St. John (1998) prefer the term "ESP practitioner" rather than ESP teacher. They stated five different roles to be accomplished by an ESP practitioner: teacher, collaborator, course designer and materials provider, researcher and evaluator.

\subsection{The ESP Practitioner as a Teacher}

The teacher's role is to build up appropriate opportunities for learning and teaching processes. Also, he/she should make use of authentic materials to increase learners' motivation as well as to apply proper teaching methodology that suits learners' needs.

\subsection{The ESP Practitioner as a Collaborator}

For better obtaining teaching experiences, the ESP practitioner has to keep in touch with other counterparts in different locations as well as the subject teachers in order to refresh and update his/her teaching awareness.

\subsection{The ESP Practitioner as a Course Designer and Material Provider}

As observed for the shortest of the materials availability for teaching ESP programs, the ESP practitioner should design his/her own syllabus, which suits the learners' needs and organize the teaching materials whether they are authentic or handmade ones.

\subsection{The ESP Practitioner as a Researcher}

The ESP practitioner should be acquainted with his/her own learners' needs such as goals and different types of their interests, and accordingly, he/she can follow researches on the subject matter and prepare the target materials. So, the syllabus 
designed and the materials prepared should cater the learners' target situation.

\subsection{The ESP Practitioner as an Evaluator}

The evaluation system is not a new step for ESP courses; it is already applied in a general English courses. In general English, the evaluation process is only for students and teaching effectivity, but in ESP, the course evaluation and teaching materials in addition to learners' assessment clearly take place. Dudley-Evans and St. John (1998) state that: the evaluation system should be an on-going process (i.e. during the course; at the end of the course, and after the finishing of the course). This process of evaluation makes the syllabus valid and up-to-date. The ESP practitioner should be familiar with the evaluation process and how to assess the learners accordingly. He/she should check the syllabus effectivity for the learners as a prior attempt to its use. Upon the learners' responses for the syllabus effectivity and the methodology followed, the next step should be the overall materials preparation.

\section{Problems and Challenges Affect Teaching ESP (Personal Experiences on ESP Courses Taught)}

As I am an ESP practitioner for years in Sudan and Saudi Arabia, I faced a lot of problems and challenges that may affect teaching practice. These problems may influence other ESP practitioners:

1) Lack of orthodoxy;

2) Lack of specialist knowledge;

3) Lack of materials;

4) Lack of learners' motivation.

\subsection{Lack of Orthodoxy}

This problem started since the emergence of ESP in its early years (Hutchinson \& Waters, 1987). It is about the "authentic materials", which lack their harmony with course intended for teaching and learning. Upon some debates, the majority of researchers believe that the authentic texts are genuine and should only be planned for native speakers. Therefore, many researchers brought different concepts about this issue. Here, I mention three scientists as an example:

David Nunan (1989: p. 54) quotes "a rule of thumb for authentic here is any material which has not been specifically produced for the purpose of the language teaching".

According to Wilkins (1976: p. 79), believes that the authentic materials are focussed on the English speaking countries.

As for Morrow (cited in Taylor 1994), thinks that authentic text is generated by those who are native speakers and used to be addressed to the same type of addressees.

\subsection{Lack of Specialist Knowledge}

Since delivering ESP courses, this matter lacks the specialists' knowledge in the 
area which I teach and it caused as a problematic issue that enable me to whom contact and cooperate with. For me, it is considered as time consuming to find or contact such specialists because they are either busy or never desire to help. So, I find the use of Internet is of great benefits which enable me a lot to look for different views and new discoveries in this important area of study.

\subsection{Lack of Materials}

It gets me a challenge to produce handmade materials or use the published ones that suit the learners' needs and interests. But I could manage to design ones of mine and use the published ones as well. The best way to teach ESP courses is through using authentic materials if available because they are helpful and save time.

\subsection{Lack of Learners' Motivation}

Teaching ESP courses should grab learners' attention and build up their motivation. Unlikely, I noticed that most of learners take ESP courses just for either obtaining the certificates or for promotion to a higher position. Therefore, teaching learners such a dynamic subject matter should be of great desire to learn and qualify them for better learning background.

\section{The Status of ESP Today}

ESP has witnessed a change in its approaches after the end of 1959s as it has been applied to communicative teaching in English language teaching courses around the world today. The point to note as a fact is that the ESP of "yesterday" (since its emergence) was only in the form of linguistic features, but the ESP of "today" demands more awareness and concentration as a linguistic unit of its own language. As stated by Robinson (1991), ESP is now regarded as a specific activity involving education, preparation and practice, and it covers three key areas of knowledge, namely, pedagogy, language, and the learners' specialized area of interest such as medicine, law, marketing, accounting, etc. That is to say, today, the center of attention is on content-based instruction rather than the conventional grammarian approach, which only concentrates on linguistic features. This is because ESP courses are normally goal-oriented and aimed at equipping learners with skills they need for academic purposes or workplace purposes; this would then enable them to comprehend and communicate more efficiently in their respective language environment. Another notable feature of ESP courses is that they are conducted over a short period of time. This means that their objectives are clearly specified and involve collaboration and negotiation with all those who are involved in the course, that is, organizers, teachers, sponsors and learners (Robinson, 1991).

\section{Conclusion}

From the above discussions related to an ESP practitioner, it is revealed that an 
ESP practitioner is required not only to be a teacher, but also to be more motivated, enthusiastic and devoted to positively affect the students' motivation towards the ESP courses. In this paper, the researcher has mentioned the roles of an ESP practitioner in details. Also, he reflected some of his personal experiences towards teaching ESP courses.

It is found that the ESP practitioner has different and complicated roles. As teacher, he/she has to help learners to learn. As course designer and material provider, his/her role is to choose handmade or authentic materials that best suit the learners' needs. As an evaluator, he/she has to participate in the evaluation system for the course, and the learners, and for the materials to be used. As researcher, he/she should be of great ability to do some researches, discovering latest findings, which improve the ESP context. As collaborator, he/she should contact other counterparts or subject teachers to equip him/her with best technological awareness to improve teaching process.

\section{Conflicts of Interest}

The author declares no conflicts of interest regarding the publication of this paper.

\section{References}

Anthony, L. (1997). English for Specific Purposes: What Does It Mean? Why Is It Different? On-CUE, 5, 9-10.

Carter, D. (1983). Some Propositions about ESP. The ESP Journal, 2, 131-137.

Cummins, J. (1979). Cognitive/Academic Language Proficiency, Linguistic Interdependence, the Optimum Age Question and Some Other Matters. Bilingualism, 19, 121-129.

Dudley-Evans, T. (1997). Five Questions for LSP Teacher Training. In R. Howard, \& G. Brown (Eds.), Teacher Education for LSP (pp. 58-67). Clevedon: Multilingual Matters.

Dudley-Evans, T., \& St. John, M. J. (1998). Developments in English for Specific Purposes: A Multi-Disciplinary Approach. Kuala Lumpur: Oxford University Press.

Fanning, P. (1993). Broadening the ESP Umbrella. English for Specific Purposes, 12, 159-170. https://doi.org/10.1016/0889-4906(93)90016-H

Hussin, S., Maarof, N., \& D’Cruz, J. V. (2000). Sustaining an Interest in Learning English and Increasing the Motivation to Learn English: An Enrichment Programme. In Millennium MICELT 2000: 3rd Malaysian International Conference for English Language Teaching.

Hutchinson, T., \& Waters, A. (1987). English for Specific Purposes: A Learning-Centred Approach. Cambridge: Cambridge University Press.

https://doi.org/10.1017/CBO9780511733031

Johns, A. M. (1991). English for Specific Purposes (ESP): Its History and Contribution. In M. Celce-Murcia (Ed.), Teaching English as a Second or Foreign Language. Boston: Heinle and Heinle.

Jordan, R. R. (1997). English for Academic Purposes. Cambridge: Cambridge University Press. https://doi.org/10.1017/CBO9780511733062

Kennedy, C., \& Bolitho, R. (1984). English for Specific Purposes. London: Macmillan.

Larson-Freeman, D. (2000). Techniques and Principles in Language Teaching. China: 
OUP.

Mackay, R. (1978). Identifying the Nature of the Learner's Needs. In R. Mackay, \& A. J. Mountford, (Eds.), English for Specific Purposes, Longman (pp. 21-42). London: Longman.

Nunan, D. (1989). Designing Tasks for Communicative Classroom. Cambridge: Cambridge University Press.

Perren, G. (1974). Forward in Teaching Languages to Adults for Special Purposes. CILT Reports and Papers, London: CILT.

Robinson, P. (1991). ESP Today: A Practitioner's Guide. Hemel Hempstead: Prentice Hall.

Robinson, P. C. (1980). ESP (English for Specific Purposes). Oxford: Pergamon Press.

Strevens, P. (1988). ESP after Twenty Years: A Re-Appraisal. In M. Tickoo (Ed.), ESP State of Art (pp. 1-13). Singapore: SEAMEO Regional Centre.

Swales, J. (1985). Episodes in ESP. Taiwan International ESP Journal, 1, 77-95.

Swales, J. (1986). Citation Analysis and Discourse Analysis. Applied Linguistics, 7, 39-56. https://doi.org/10.1093/applin/7.1.39

Taylor, D. (1994). Inauthentic Authenticity or Authentic in Authenticity? The Electronic Journal for English as a Second Language, 1, A-1.

Widdowson, H. G. (1978). Teaching Language as Communication. O.U.P.

Wilkins, D. (1976). Notional Syllabuses. Oxford: Oxford University Press.

William, K. (2010). In What Ways, If Any, Does the Role of the ESP Teacher Differ from That of a Teacher of GE? And to What Extent Is It Necessary for the Teacher of ESP to Have Knowledge of the Student's Subject or Professional Discipline? http://Studymode.com/essays.html 